\title{
Habitat preference and life history of the mayflies Metamonius anceps Eaton (Nesameletidae) and Meridialaris chiloeensis Demoulin (Leptophlebiidae) in a Patagonian mountain stream
}

\author{
M.E.T. Hollmann \& M.L. Miserendino*
}

LIESA. Laboratorio de Investigaciones en Ecología y Sistemática Animal. Universidad Nacional de la Patagonia. Sarmiento 849. 9200 Esquel, Chubut, Argentina.

\begin{abstract}
The habitat preferences, temporal dynamics in density and the life history of two species of mayflies, Metamonius anceps and Meridialaris chiloeensis, were investigated in a Patagonian mountain stream over a period of one year. Benthic samples were taken in a low order Nothofagus forested stream. M. anceps was univoltine with small nymphs predominating in winter and emergence occurring in summer. M. chiloeensis showed a bivoltine life cycle with a winter and summer generation, and emergence period in spring and summer. Both species were significantly more abundant in the low water period than in the high discharge season. Gravels supported significantly more individuals of M. chiloeensis than sand in pools and leaf packs. Temporal overlap of abundance between species was low. The existence of different life history strategies and the temporal shift of main generations and density peaks were critical to allow species coexistence.
\end{abstract}

Keywords: insects, Ephemeroptera, life cycle, ecology, river, habitat preference

\section{Introduction}

Ephemeroptera nymphs are a conspicuous component of the macroinvertebrate fauna in mountain streams (Edmunds \& Waltz 1996). In running waters of Argentina mayflies are represented by twelve families (Domínguez et al. 2001). In Patagonia, the family Leptophlebiidae is very diverse and widely distributed (Domínguez et al. 1994), among leptophlebiids genus Meridialaris shows a broad distribution range $\left(26^{\circ}\right.$ to $55^{\circ} \mathrm{S}$ ). M. laminata (Ulmer), M. diguillina (Demoulin) and $M$. chiloeense (Demoulin) are very abundant in the region. On the other hand, Nesameletidae (= Siphlonuridae), of amphinotic distribution, is represented only by Metamonius which is distributed from $33^{\circ}$ to $55^{\circ} \mathrm{S}$ including the coastal range in Chile and headwaters in the Cordillera (Chile and Argentina) (Mercado \& Elliot 2004). In the last decade, the knowledge of Ephemeroptera in the area has gained attention. The altitudinal distribution of mayfly species and their environmental relationships has been described in rivers of the

\footnotetext{
* Corresponding author : E-mail : lmiserendino@liesa.org.ar
}

Cordillera and the Plateau (Miserendino \& Pizzolón 2000, 2001). Mayfly communities have also been utilized to assess organic pollution and to evaluate the land use effects in some watersheds (Miserendino 2001). However, despite the common occurrence of mayflies in streams and rivers in Patagonia there have been few studies on their life histories (Gonser \& Spies 1997).

Some Northern hemisphere studies on aquatic insects suggest that life histories are tuned to the seasonal availability of food, and that related species are temporally segregated (Vannote et al. 1980). In contrast some stream insects in the Southern Hemisphere, such as those in New Zealand, have been characterized as having flexible, poorly synchronized life histories with non-seasonal patterns of development and extended flight periods (Winterbourn et al. 1981). This apparent flexibility may be related to climatic stability, unpredictability of discharge, and a greater continuity in supply of allochthonous inputs (Winterbourn 1995, Scarsbrook 2000). The running water fauna of Patagonia shows strong biogeographical affinities with that of New Zealand (Boothroyd 2000, Hitchings \& Staniczek 2003). However, rivers in the Patagonian Mountains are more predictable in terms of discharge and one might expect the life cycles of 
stream insects to demonstrate a greater degree of synchrony in growth (Miserendino \& Pizzolón 2003).

In previous studies carried out in the Esquel-Percy River drainage system, Metamonius anceps and Meridialaris chiloeense were abundant and frequently recorded at headwaters (Miserendino \& Pizzolón 2000, 2001). Information about their feeding habits is available; M. chiloeensis feeds on periphyton (Díaz Villanueva et al. 2004) and $M$. anceps shows gut contents dominated by fine detritus and diatoms (Hollmann \& Miserendino 2004), both species being categorized as grazers. Finally, an important environmental database from La Hoya stream exists from earlier investigations. For these reasons we planned to achieve our research with these two species. Because the knowledge of life cycles greatly contributes to understand benthic community dynamics in rivers (Ward 1992), we propose 1) to describe the life cycle and to analyze synchrony in growth of two mayflies species $M$. chiloeensis and $M$. anceps, and 2) to assess their habitat preferences in a headwater stream in Patagonia.

\section{Study area and methods}

La Hoya stream is a $2^{\text {nd }}$ order watercourse in the Esquel-Percy river drainage system in the Northwest of the Chubut Province. The study site (42 50 '27.8" S and $71^{\circ} 15^{\prime} 54.8^{\prime} \mathrm{W}$ ) is located in the mountainous zone at 1237 m.a.s.l. The riparian forest is composed mainly by the deciduous Nothofagus pumilio (lenga), the native shrubs Fuchsia magellanica, Ribes magellanicum, Mulinum spinosum and the herbaceous Stipa sp. (León et al. 1998).

At the selected reach, substrate composition was estimated as percentage of each fraction: boulder, cobble, gravel, pebble and sand. The relative proportion of substrate was assessed using a grid $\left(1 \mathrm{~m}^{2}\right)$ (Gordon et al. 1994). Air and water temperature, depth and stream width were measured in a monthly basis whereas current velocity and discharge were recorded bimonthly. Average depth was calculated from five measurements from one transversal profile across the channel with a calibrate stick.

In order to analyze seasonal variation in abundance and to describe the life cycles, larvae were collected monthly from July 2004 to June 2005. Samples were collected with a Surber net $\left(0.09 \mathrm{~m}^{-2} ; 250 \mu\right.$ mesh size $)$, at each occasion three replicates were taken on riffles. In order to collect more larval instars for the life history description, eight additional Surber samples were taken and pooled on each sampling date. Samples were fixed with $4 \%$ formaldehyde solution. At the laboratory samples were sorted out under $5 \mathrm{x}$ magnification and then stored in $70 \%$ ethyl alcohol.

\section{Life cycle analyses}

To describe life cycles of the species, 2,969 larvae of $M$. chiloeensis and 329 larvae of $M$. anceps were measured. In the case of $M$. chiloeensis nymphs the body length was measured under a stereomicroscope (8X) (Huryn 1996, Buffagni \& Gomba 1996, Gonser \& Spies 1997). Abdomen length was used as a measure of the body size in $M$. anceps. It was measured with an $8 \mathrm{X}$ magnification from the first segment to the posterior tip of the abdomen, excluding cerci and telofilum (Winterbourn 2003). Adults were caught using a sweep net and a light trap combined with a white fabric as suggested by Domínguez et al. (2001). Larvae and adults were identified using regional keys (Domínguez et al. 1994, Mercado \& Elliot 2004).

\section{Habitat sampling}

Another sampling was undertaken during high (September 2004) and low water periods (February 2005). In depositional areas (pools) two habitat types were sampled: sand and boulders. In run-riffle areas three different habitats were studied: boulders, gravel and leaf packs. Three Surber samples were taken from each habitat during the dry and wet seasons $(n=30)$. We chose this sampler because a previous survey in high gradient, low order streams in Patagonia, showed consistent results to distinguish benthos communities among different habitats (Velásquez \& Miserendino 2003). To prevent small organisms escapes from debris, all material collected from leaf-packs was carefully washed and processed in the laboratory. Fixed-effects 2-factor ANOVA models were used to assess significant differences in total density between habitats (5), and dates (2). The interaction between habitat and season was also assessed. A posteriori comparisons among habitats were performed with Tukey's (HSD) test $(p<0.05)$. The overlapping of the utilized habitat between both mayflies species during the low and the high water period was calculated with the proportional similarity index (PS) (Whittaker 1975). Values may range from 0 (no overlap) to 1 (total overlap).

\section{Results}

\section{Environmental features}

Temperature ranged from $1-12{ }^{\circ} \mathrm{C}$. Minimal water depth was $17 \mathrm{~cm}$ and maximum $30 \mathrm{~cm}$. Stream width var- 
ied from 2 to $5 \mathrm{~m}$ during the low and high water periods respectively. As in other head water streams with an important slope current velocity varied between 0.55 and $0.83 \mathrm{~m} . \mathrm{s}^{-1}$. Minimum discharge was $0.187 \mathrm{~m}^{3} \cdot \mathrm{s}^{-1}$ in February and maximum discharge was $1.245 \mathrm{~m}^{3} . \mathrm{s}^{-1}$ in September (Table 1). Substratum was dominated by boulders $(25 \%)$ and cobbles (35\%), being pebbles $(10 \%)$, gravel $(20 \%)$, and sand (20\%) well represented.

Table 1. Range, mean and standard deviation of the main environmental features of la Hoya Stream during the study period.

\begin{tabular}{lc}
\hline \multicolumn{1}{c}{ Variables } & $\begin{array}{c}\text { Minimum-Maximum } \\
\text { Mean }( \pm \text { SD })\end{array}$ \\
\hline Air Temperature $\left({ }^{\circ} \mathrm{C}\right)$ & $-3 / 16.5$ \\
& $(7.85 \pm 6.70)$ \\
Water Temperature $\left({ }^{\circ} \mathrm{C}\right)$ & $1 / 12$ \\
& $(4.75 \pm 3.55)$ \\
Depth $(\mathrm{cm})$ & $17 / 30$ \\
& $(22 \pm 11)$ \\
Width $(\mathrm{m})$ & $2-5$ \\
& $(3.4 \pm 0.85)$ \\
Current Velocity $\left(\mathrm{m}^{\mathrm{s}} \mathrm{s}^{-1}\right)$ & $0.55 / 0.83$ \\
& $(0.67 \pm 0.10)$ \\
Discharge $\left(\mathrm{m}^{3} \cdot \mathrm{s}^{-1}\right)$ & $0.187 / 1.245$ \\
& $(0.44 \pm 0.22)$
\end{tabular}

\section{Life histories}

M. chiloeensis: Maximum density of nymph was recorded in March (1300 ind. $\mathrm{m}^{-2}$ ). In February larvae were absent in density samples; minimum densities were recorded in September (126 ind. $\mathrm{m}^{-2}$ ) and May (170 ind. $\mathrm{m}^{-2}$ ) (Fig. 1 a). M. chiloeensis had a bivoltine life cycle with a winter and a summer generation (Fig. 2). Overlapping generations were observed in January and February. Large collections of nymphs obtained in October and February were dominated by small individuals. Final-instar nymphs were collected in September, December, January and February. Subimagoes and adults were collected on sweep nets and traps in January and February.

M. anceps: $M$. anceps nymphs peaked in January (55 ind. $\mathrm{m}^{-2}$ ), they were absent in July and May (Fig. 1 b). Metamonius anceps, had a moderately synchronized, univoltine life cycle (Fig. 3). Very small nymphs were found in July. Medium-large sized nymphs predominated in September, October and from December to March; however a wide range of size classes was present
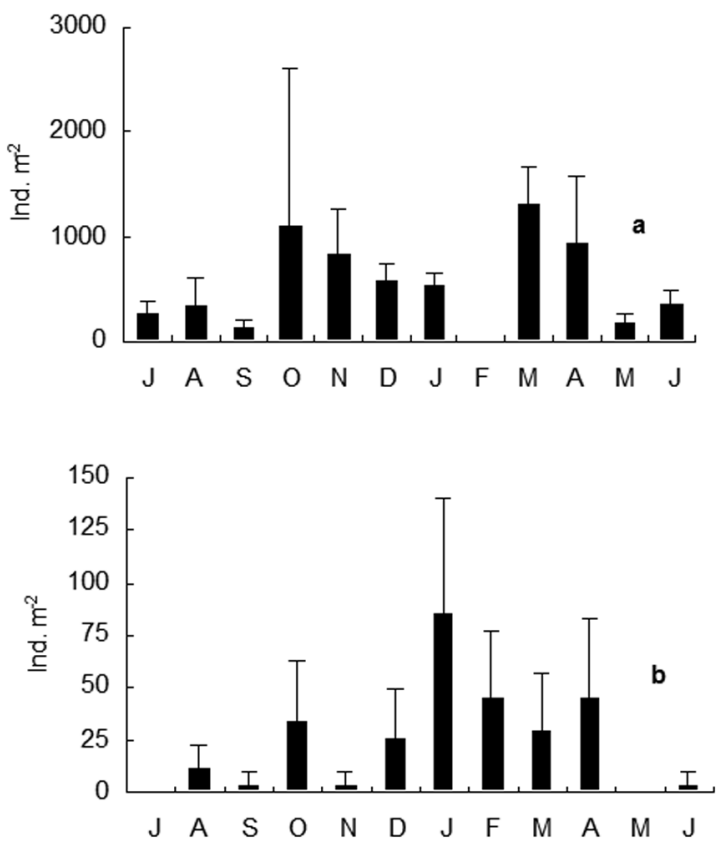

Fig. 1. Mean density per sample of a) Meridialaris chiloeensis and b) Metamonius anceps in La Hoya Stream during the study period. Data are mean values $( \pm \mathrm{SD})$ and $n=3$.

at several months. Final instar nymphs were taken in monthly samples in September, October, February and April. We captured one adult in February.

\section{Habitat selection}

Gravel in riffle areas supported significantly more individuals of $M$. chiloeensis than leaf packs and sand in pools (Fig. 4) (ANOVA, $\mathrm{P}<0.002$ ). Boulders in riffles had lower densities of $M$. anceps than the other habitats; however values were not significantly different among sampled habitats (ANOVA, $\mathrm{P}<0.06$, Table 2). For both species, densities reported during the low water period were significantly higher than those of the high water period (season effect) (Fig. 4, Table 2). Excepting the sand habitat in pools, M. chiloeensis showed significantly higher densities in the low water period than at high water period in all habitat types (season and habitat interaction, Table 2).

Interespecific overlap in density of species among habitat types was relatively low (PS values $<0.3$ ), maximum values of PS being observed in boulder in pools during the high water period, and in leaf-packs, boulder in pools and sand in pools during the low water period (Table 3). 

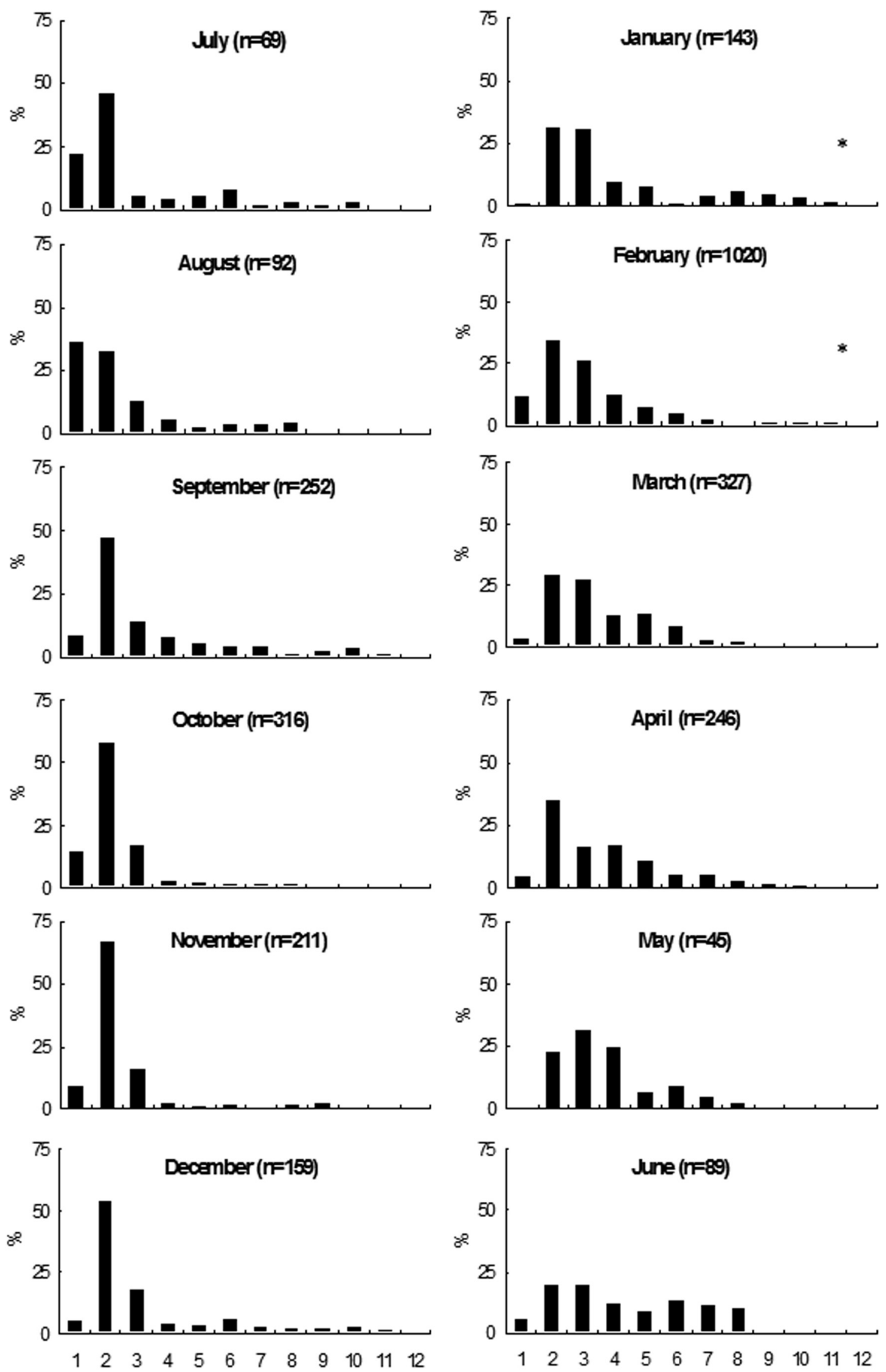

Body Length $(\mathrm{mm})$

Fig. 2. Size-frequency distributions of Meridialaris chiloeensis larvae in La Hoya stream from July 2004 to June 2005, * indicate that adults were caught on the sampling date. $n$ is indicated next to the months. 

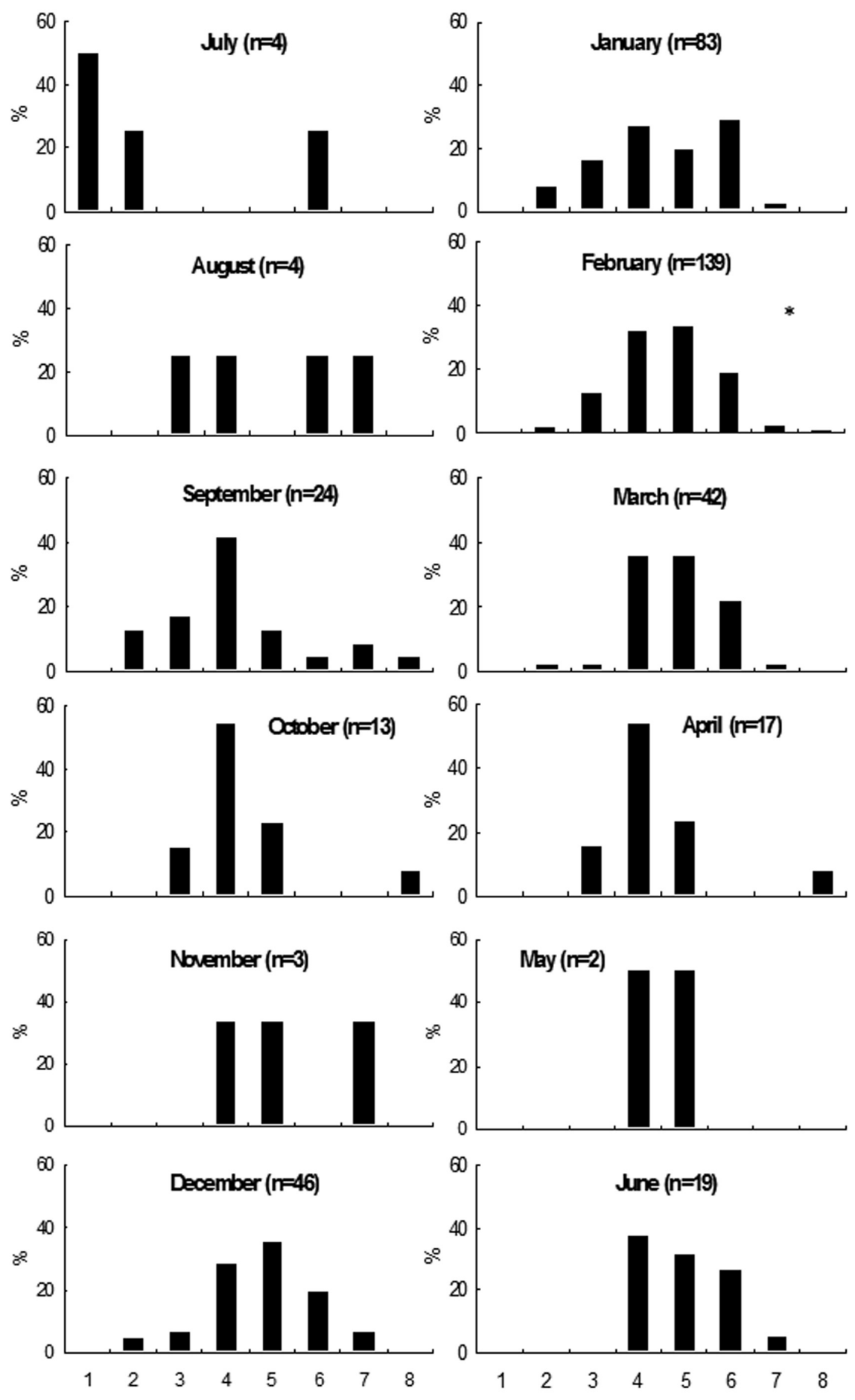

Abdomen Length $(\mathrm{mm})$

Fig. 3. Size-frequency distributions of Metamonius anceps larvae in La Hoya stream from July 2004 to June 2005, * indicate that adults were caught on the sampling date. $n$ is indicated next to the months. 

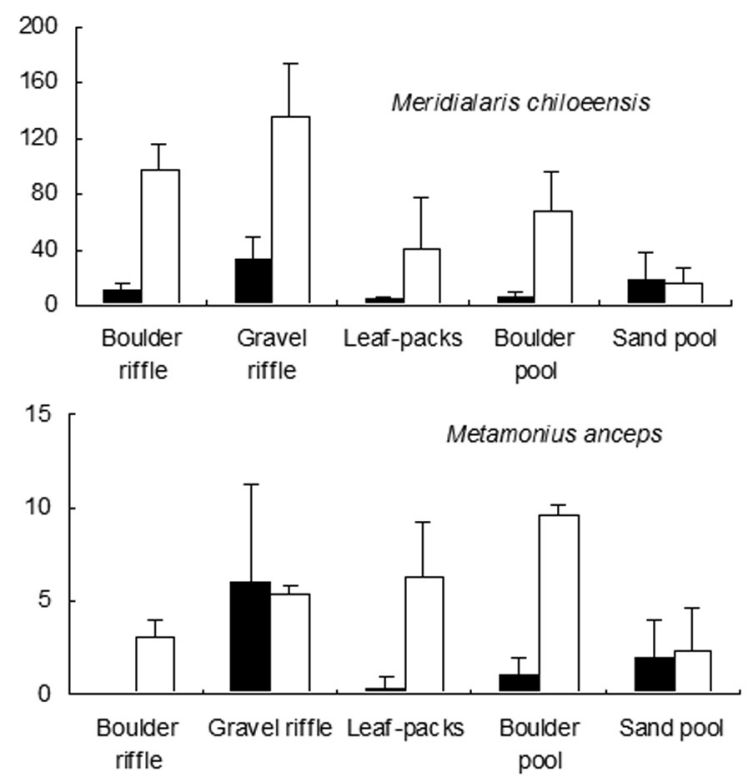

Fig. 4. Inter-habitat variation of M. chiloeensis and M. anceps $(n=3)$ during the low water period (open bars) and high water period (black bars). Data are mean individuals per sample ( $\pm 1 \mathrm{SE})$.

Table 2. Results of two-way ANOVAs examining the effects of habitat type and season on total density of $M$. chiloeensis $(n=1297)$ and $M$. anceps $(n=108)$ in La Hoya stream. Variables $\log (\mathrm{x}+1)$ transformed, significant differences in boldface.

\begin{tabular}{lcccc}
\hline & df & $\begin{array}{c}\text { Ms } \\
\text { Effect }\end{array}$ & F & p \\
\hline $\begin{array}{l}\text { Meridialaris } \\
\text { chiloeensis }\end{array}$ & & & & \\
Season & 1 & 3.16 & 36.11 & $\mathbf{0 . 0 0 1}$ \\
Habitat & 4 & 0.56 & 6.38 & $\mathbf{0 . 0 0 2}$ \\
Season x Habitat & 4 & 0.30 & 3.41 & $\mathbf{0 . 0 3}$ \\
Metamonius & & & & \\
anceps & & & & \\
Season & 1 & 1.58 & 23.3 & $\mathbf{0 . 0 0 1}$ \\
Habitat & 4 & 0.18 & 2.68 & 0.06 \\
Season x Habitat & 4 & 0.17 & 2.46 & 0.07 \\
\hline
\end{tabular}

\section{Discussion}

The life cycle of $M$. chiloeensis was similar to that reported for the co-generic $M$. diguillina Ulmer by Gonser \& Spies (1997) in the Estero Pirén stream at a lower latitude in Chile. The authors also observed poor developmental synchronization, and generation overlapping
Table 3. Interspecific habitat overlap for $M$. chiloeensis and $M$. anceps during high and low water period in La Hoya stream. Proportional similarity index values are presented $(0=$ no overlap and $1=$ total overlap).

\begin{tabular}{ccc}
\hline & $\begin{array}{c}\text { High water } \\
\text { period }\end{array}$ & $\begin{array}{c}\text { Low water } \\
\text { period }\end{array}$ \\
\hline Boulder riffle & 0 & 0.06 \\
Gravel riffle & 0.3 & 0.07 \\
Leaf-packs & 0.15 & 0.27 \\
Boulder pool & 0.25 & 0.25 \\
Sand pool & 0.19 & 0.26 \\
\hline
\end{tabular}

occurring in January/February and April. A bivoltine life cycle with a winter-summer cycle was described for the leptophlepbiid Deleatidium in two upland streams in Otago (New Zealand), albeit with a low degree of synchrony (Huryn 1996). This type of life cycle is characterized by an overwintering nymphal stage that completes its development in late spring, followed by a rapid summer generation. In La Hoya stream the relatively high number of larvae of $M$. chiloeensis about to emerge in January and February together with high numbers of small larvae in February suggest the occurrence of a winter generation that developed during autumn and winter with emergence taking place in September. A second more defined summer generation appeared in September-October with most individuals emerging from January to February. These results are also consistent with those observed by Scrimgeour (1991) for Deleatidium lilli in the Ashley River and by Huryn (1996) for the same species in the Sutton Stream (New Zealand). In Deleatidium the predominance of poorly synchronized life cycles and of cohorts with long flight periods would provide opportunities for intermediate growth and reproduction following spates (Scrimgeour 1991). It has been stated that the asynchronous development spreads life stages over time, thereby decreasing the risk of eradication by short term catastrophic events such as drought or spates. In a temporary stream in Oregon an extended hatching period in the leptophlebiid Paraleptophlebia gregalis resulted in the presence of early instar larvae during most part of the year, and was the key to asynchronous development and prolonged emergence periods (Dietercih \& Anderson 1995). As we mentioned, as a headwater channel, La Hoya stream is an environment with a marked seasonality. Snowfall starts in May and the rainfall takes place from May to September. It is also predictable in terms of discharge with greater spates occurring mostly during the spring snowmelt. However, the observed pattern for $M$. chiloeensse would not fit with 
stable environmental conditions of predictable discharge patterns as we expected. It is possible that a long period of high discharge (over six months) generates a physically harsh environment for this species. Our observations suggest that overlapping generations of $M$. chiloeensis took place in January but also in September, the month in which snowmelt was highest. Almost likely, an increase in temperature in September played a crucial role assuring adult emergence for the winter generation.

Our results show that $M$. chiloeensis preferred inorganic and stable substrates in run riffle areas, which is in agreement with the findings of Velázquez \& Miserendino (2003). The study carried out in four rivers in the Cordillera suggested that $M$. chiloeensis seemed to be more habitat specific than $M$. laminata and $M$. diguillina, $M$. chiloeensis being strongly associated to the bouldercobble-pebble habitats. Thus, M. chiloeensis was linked to more stable substrate in terms of persistence. On the other hand, $M$. laminata seemed to be very abundant in sand, macrophytes and gravel and $M$. diguillina more related to cobble and leaf-packs. At the river scale, a strong spatial segregation in the distribution of Meridialaris species seemed to occur, $M$. chiloeensis being restricted to the lower order sections and more diluted waters, and M. laminata clearly more abundant in the mean-high stream orders. M. diguilina appeared as eurizonal (Miserendino \& Pizzolón 2000, 2001). Altitudinal zonation of Ephemeroptera species in temperate areas has been reported by Ward (1986). Domínguez \& Ballesteros Valdez (1992) also observed a marked longitudinal replacement of leptophlebiid species in an Argentinean subtropical river. Gonzálezetal.(2003)recorded temporal and spatial segregation reducing interspecific competition for two leptophlebiids in a Northern Spain stream at similar latitudes to those of the present study.

In this study the life cycle of $M$. anceps was consistent with those reported for two Nesameletus species in a mountain stream in New Zealand at similar latitudes (Winterbourn 2003). Both species were univoltine with small nymphs predominating in autumn-early winter and emergence taking place in spring and summer; moreover species showed a wide range of size classes present in winter months. Similarly, Campbell (1986) reported a life history poorly synchronized with adult emergence extending over five months for the Australian Nesameletidae Ameletoides sp. According to Mercado and Elliot (2004) the emergence period observed for adults of $M$. anceps seems to be shorter in the Chilean side, with the flight phase of the species happening in spring, mostly from November to January.

Interestingly we did not find evidence of habitat selection for M. anceps in our study. It is possible that larvae of
$M$. anceps were difficult to sample quantitatively with benthic samplers because of their rapid swimming movements, this was noticed by McIntosh (2002) for other Nesameletidae species. Similarly, Winterbourn (2003) found that Nesameletus nymphs were very abundant in drift samples. $M$. anceps seems to be restricted to forested habitats and present over elevations of 1000 m.a.s.l. at least in this latitude (Miserendino \& Pizzolón 2001). A recent review of the genera reported Metamonius in small mountain streams with cold, well-aerated waters, typically in the headwaters reaches of streams (Mercado \& Elliot 2004). As other Nesameletidae species that occur in New Zealand streams (Hitchings \& Staniczeck 2003) Metamonius would be associated to areas little perturbed by human activity.

The temporal density pattern observed in both $M$. chiloeensis and $M$. anceps was consistent with a previous research carried out at the same stream in 1991-1992 (Miserendino \& Pizzolón, 2000) with maximum density reported in March for M. chiloeensis and in January for $M$. anceps. The decrease in density observed during the rainy season is a common feature in benthic communities of rivers and streams in the Cordillera (Miserendino \& Pizzolón 2003, 2004). Reduced number of invertebrate densities following spates may not only represent mortality but also displacement of invertebrates. Invertebrate populations may redistribute themselves via behavioral drift and crawling from refuges occupied during floods (hyporheos, stream margins, instream debris, backwaters) (Scrimgeour 1991).

In conclusion, our study suggest that $M$. chiloeensis had a bivoltine life cycle while $M$. anceps was univoltine, nevertheless synchronization in growth was lower than we expected. M. chiloeensis showed some habitat preference while in $M$. anceps this was not observed. We found a low overlap of the utilized habitat types between species. As suggested by several authors (Sweeney \&Vannote 1981, Brittain 1991) competition between related mayfly species may be reduced by temporal and spatial segregation. We think that the existence of different life history strategies in the studied species and a temporal shift of main generations and density peaks were crucial to allow species coexistence in la Hoya stream.

\section{Acknowledgements}

Special thanks to G. Alday, C. Di Prinzio, P. Diaz, A. Humai, A. Gómez and R. Magallanes for valuable help during the sampling and to C. Brand for laboratory assistance. We are grateful to Dr. Miguel Archangelsky for helpful comments on the English version of the paper. We thank an anonymous reviewer for valuable observations that greatly improved the manuscript. This is Scientific Contribution $n^{\circ} 11$ from LIESA. 


\section{References}

Boothroyd I. 2000. - Biogeography and diversity. Pages 30-52 in New Zealand stream invertebrates: ecology and implications for management Collier, K. J. Winterbourn, M. J. (eds). Christchurch, New Zealand Limnological Society.

Buffagni A. \& Gomba T. 1996. - Larval development and ecology of Baetis liebebnauae Keffermüller (Ephemeroptera: Baetidae) in a north Italian lowland spring. Ann. Limnol., 32, 221-228.

Brittain J. 1991. - Life history characteristics as a determinant of the response of mayflies and stoneflies to man-made environmental disturbance (Ephemeroptera and Plecoptera). Pages 539-546 in Overview and strategies of Ephemeroptera and Plecoptera. AlbaTercedor J. \& Sanchez Ortega, A. (eds). Sandhill Crane Press. Gainesville, Fla. USA.

Campbell I.C. 1986. - Life histories of some Australian Siphlonurid and Oligoneuriid mayflies (Insecta: Ephemeroptera). Australian Journal of Marine and Freshwater Research, 37, 261-188.

Dieterich M. \& Anderson N.H. 1995. - Life cycles and food habits of mayflies and stoneflies from temporary streams in western Oregon. Freshwat. Biol., 34, 47-60. Díaz Villanueva V. \& Modenutti B. 2004. - Experimental analysis of grazing by the mayfly Meridialaris chiloeensis on different successional stages of stream periphyton. Int. Rev. Hydrobiol., 89, 263-277.

Domínguez E. \& Ballesteros Valdez J.M. 1992. - Altitudinal replacement of Ephemeroptera in a subtropical river. Hydrobiologia, 246, 83-88.

Domínguez E., Hubbard M.D. \& Pescador M.L. 1994. - Los Ephemeroptera de Argentina. Fauna de Agua Dulce de la Rca Argentina. 33. Fascículo 1.

Domínguez E., Hubbard M.D., Pescador M.L. \& Molineri C. 2001. - Ephemeroptera. Pages 17-54 In: Guía para la determinación de artrópodos bentónicos sudamericanos Fernández H.R. \& Domínguez E. (Eds.). Editorial Universitaria de Tucumán.

Edmunds G.F. \& Waltz R.D. 1996. - Ephemeroptera. Pages 126-163 In: An introduction to the aquatic insects of North America. Merritt R.W. \& Cummins K.W. (eds.) Kendall/Hunt Publishing Company, Iowa, USA.

Gonser T. \& Spies M. 1997. - Southern Hemisphere Symbiocladius (Diptera, Chironomidae) and Their Mayfly Hosts (Ephemeroptera, Leptophlebiidae). Pages 455-466 In: Ephemeroptera \& Plecoptera: Biology-Ecology-Systematics. Landolt \& Sartori (eds.). MTL-Mauron Tinguely \& Lachat SA. Switzerland.

González J.M. Basaguren A. \& Pozo J. 2003. - Life history, production and coexistence of two leptophlebiid mayflies in three sites along a Northern Spain stream. Arch. Hydrobiol., 3, 303318.

Gordon, N.D, Mc Mahon T.A. \& Finlayson B.L. 1994. - Stream Hydrology, an Introduction for Ecologists. Wiley \& Sons. New York. pp. 526

Hitchings T.R. \& Staniczek A.H. 2003. - Fauna New Zealand. Ko te Aitanga Pepeke o Aotearoa. $\mathrm{N}^{\circ}$ 46. Nesameletidae. Edit. Manaaki Whenua press. $72 \mathrm{pp}$.

Hollmann M.E.T \& Miserendino M.L. 2004. - Habitat y composición de la dieta de larvas de Metamonius anceps (Ephemeroptera) y Senzilloides panguipulli (Plecoptera) en arroyos de montaña en Patagonia. Resúmenes de la II Reunión Binacional de Ecología., Mendoza. Argentina, p 171.

Huryn A.D. 1996. - Temperature-dependent growth and life cycle of Deleatidium (Ephemeroptera: Leptophlebiidae) in two high country streams in New Zealand. Freshwat. Biol., 36, 351-361.
León R., Bran D., Collantes M., Paruelo, J.M. \& Soriano A. 1998. Grandes unidades de vegetación de la Patagonia extra andina. Ecología Austral, 8, 125-144.

Mc Intosh A.R. 2002. - Impact of introduced trout on Nesameletus mayfly populations measured using electrofishing. Arch. Hydrobiol., 154, 375-392.

Mercado M. \& Elliot S. 2004. - Taxonomic Revision of de Genus Metamonius Eaton (Nesameletidae: Ephemeroptera), with Notes on its Biology and Distribution. Stud. Neotrop. Fauna. E., 39, 149-157.

Miserendino M.L. 2001. - Macroinvertebrate assemblages in Andean Patagonian rivers and streams. Hydrobiologia, 444, $147-$ 158.

Miserendino M.L., \& Pizzolón L.A. 2000. - Macroinvertebrates of a fluvial system in Patagonia: altitudinal zonation and functional structure. Arch. Hydrobiol., 150, 55-83.

Miserendino M. L \& Pizzolón L. A. 2001. - Abundance and altitudinal distribution of Ephemeroptera in lotic AndeanPatagonic system (Argentina). Pages 135-142. In: Trends in Research in Ephemeroptera and Plecoptera, Domínguez E. (Ed.), Kluwer Academic/Plenum Publishers. New York.

Miserendino M.L. \& Pizzolón L.A. 2003. - Distribution of macroinvertebrate assemblages in the Azul-Quemquemtreu river basin, Patagonia, Argentina. New Zeal. J. Mar. Fresh., 23 (3), 525-539.

Miserendino M.L. \& Pizzolón L.A. 2004. - Interactive effects of basin features and land use change on macroinvertebrate communities of headwater streams in the Patagonian Andes. River Res. App., 20 (8), 967-982.

Scarsbrook M.R. 2000. - Life histories. pages 76-99, In New Zealand stream invertebrates: Ecology and implications for management. Collier K. J. \& Winterbourn M. J. (Eds). NIWA. New Zealand.

Scrimgeour G.J. 1991. - Life history and production of Deleatidium (Ephemeroptera: Leptophlebiidae) in an unstable New Zealand river. New Zeal. J. Mar. Fresh., 25, 93-99.

Sweeney B.W. \& Vannote R.L. 1981. - Ephemerella mayflies of White Clay Creek: bioenergetic and ecological relationships among six coexisting species. Ecology, 62 (5),1353-1369.

Vanotte R.L., Minshall G.W., Cummins K.W., Sedell J.R. \& Cushing C.E., 1980. - The river continuum concept. Can. J. Fish. Aquat. Sci., 37, 130-137.

Velásquez S.M. \& Miserendino M.L. 2003. - Habitat type and macroinvertebrate assemblages in low order Patagonian streams. Arch. Hydrobiol., 158 (4), 461-483.

Ward J.V. 1992. - Aquatic insect ecology. John Wiley \& Sons, Inc. $438 \mathrm{pp}$.

Ward, J.V. 1986. Altitudinal zonation in a Rocky Mountain stream. Arch. Hydrobiol., 74. 2, 133-199.

Winterbour M.J. 1981. - Are New Zealand stream ecosystem really different? New Zeal. J. Mar. Fresh., 15, 321-328.

Winterbourn M.J. 1995. - Rivers and streams of New Zealand. Pages 695-716 in Ecosystems of the world: River and Stream Ecosystems, Cushing C.E., Cummins K. W. \& Minshall G. W. (eds.). Elsevier. New York.

Winterbourn M.J. 2003. - Habitat Segregation and nymphal Life History of two Nesameletus Species (Ephemeroptera: Nesameletidae) in a Montain Stream, Aquat Insects, 25, 41-50.

Whittaker, R.H. - Communities and ecosystems. $2^{\text {nd }}$ edition. Mc Millan. New York. 